\title{
How You Teach Matters! An Exploratory Study on the Relationship between Teaching Models and Learning Outcomes in Entrepreneurship Education
}

\author{
Ilaria Cascavilla *, Davide Hahn (D) and Tommaso Minola \\ Center for Young and Family Engineering and Enterprise, Department of Management, Information and \\ Production, University of Bergamo, 24044 Bergamo, Italy; davide.hahn@unibg.it (D.H.); \\ tommaso.minola@unibg.it (T.M.) \\ * Correspondence: ilaria.cascavilla@unibg.it
}

check for

updates

Citation: Cascavilla, Ilaria, Davide

Hahn, and Tommaso Minola. 2022.

How You Teach Matters! An

Exploratory Study on the

Relationship between Teaching

Models and Learning Outcomes in

Entrepreneurship Education.

Administrative Sciences 12: 12.

https://doi.org/10.3390/

admsci12010012

Received: 6 August 2021

Accepted: 14 January 2022

Published: 18 January 2022

Publisher's Note: MDPI stays neutral with regard to jurisdictional claims in published maps and institutional affiliations.

Copyright: (C) 2022 by the authors. Licensee MDPI, Basel, Switzerland. This article is an open access article distributed under the terms and conditions of the Creative Commons Attribution (CC BY) license (https:// creativecommons.org/licenses/by/ $4.0 /)$.

\begin{abstract}
Although entrepreneurship can be taught in different ways, entrepreneurship education impact studies generally fall short with regard to acknowledging the teaching models of the programs they assess. This severely limits our understanding of how entrepreneurship education actually works. To address this gap, this study describes and implements a procedure to identify the teaching models of entrepreneurship education courses and shows how different teaching models are associated with entrepreneurial learning outcomes. Our analysis is based on a sample of 376 Italian university students who responded to the Global University Entrepreneurial Spirit Students' Survey (GUESSS) and attended entrepreneurship education courses. We describe and implement a coding procedure that allows us to classify the entrepreneurship courses attended by the respondents into five different teaching models (Supply, Supply-Demand, Demand, Demand-Competence and Competence). We find that courses based on the Supply-Demand, Demand and Demand-Competence Models are associated with better entrepreneurial learning outcomes than those based on the Supply Model. Our findings contribute to the theory and practice of entrepreneurship education program evaluation and design.
\end{abstract}

Keywords: entrepreneurship education; entrepreneurial learning outcomes; global university entrepreneurial spirit students' survey (GUESSS); teaching models; university students

\section{Introduction}

Entrepreneurship Education (EE), defined as a set of educational offerings aimed at preparing students to identify and act upon value-creating opportunities (Lackéus 2015, 2020; Shane and Venkataraman 2000), occupies a central role in academic debates and university practice (Eesley and Lee 2020; Hahn et al. 2020; Lyons and Zhang 2018) for its multiple benefits on students' skills and careers, as well on society (Lackéus 2015, 2020; Martin et al. 2013). In fact, besides preparing university students to create firms, generate new jobs and foster innovation (Åstebro and Hoos 2021; Eesley and Lee 2020; Shah and Pahnke 2014), EE can foster skills, such as creativity, problem-solving, extraversion and conscientiousness, useful in any career students will eventually undertake (Karlsson and Moberg 2013).

As a result, in the last decade, courses and programs related to entrepreneurship and extracurricular activities have been growing in popularity at all levels of higher education institutions, and are increasingly attracting the interest of policymakers and higher-education managers (Lackéus and Sävetun 2019; Maguire and Lunati 2009). A growth pattern can also be seen in the heterogeneity and variety of entrepreneurship programs and the courses purposes, teaching models and approaches (Hahn et al. 2017; Nabi et al. 2017; O'Connor 2013; Rideout and Gray 2013). EE can be taught in many different ways within and across universities based on topics and contents, objectives, pedagogies and teaching methods 
(Naia et al. 2014). Research has attempted to characterise the varied approaches to teaching entrepreneurship, for example, by acknowledging the distinction between "education about entrepreneurship" versus "education for entrepreneurship" (Lackéus 2020) and between theoretically versus practically oriented courses (Piperopoulos and Dimov 2015) and by discussing the pedagogy-andragogy continuum (Hägg and Kurczewska 2019).

To deal with the heterogeneity in EE offerings, the literature offers an analytical framework that classifies teaching models into five different types (Béchard and Grégoire 2005; Nabi et al. 2017): (i) the Supply Model, which is mainly based on frontal lectures; (ii) the Demand Model, which is mainly based on classroom experiences; and (iii) the Competence Model, which is primarily based on tackling real-world problems or opportunities. There are also two hybrid models: (iv) the Supply-Demand Model, based on a mix of traditional lectures and classroom experiences; and (v) the Demand-Competence Model, based on a mix of classroom experiences and real-life problems to be solved.

However, despite the value of such conceptual efforts to characterise EE teaching models, in the growing body of research assessing the impact of EE, very few works (e.g., Padilla-Angulo et al. 2021; Sansone et al. 2021) take advantage of such an analytical framework to describe the EE intervention(s) under analysis in detail (Nabi et al. 2017; Naia et al. 2014; Rideout and Gray 2013). This substantially limits our understanding of EE processes and the circumstances in which EE actually works (better), especially in terms of actual outcomes, such as learning (Hahn et al. 2017). Therefore, scholars call for a deeper conceptualisation of EE teaching models in empirical EE impact studies (Carpenter and Wilson 2021; Yi and Duval-Couetil 2021). From a more practical point of view, this matters because a growing body of research indicates that, by addressing certain aspects of the teaching models, the effectiveness of EE offerings can be radically improved (Astebro and Hoos 2021).

In response to such a call for further research, in this study, we explore the following research question: "How are different EE teaching models and students' entrepreneurial learning interrelated?" To address this research question, in this study, we employ two processes. First, we describe and implement a rigorous and replicable coding approach to classify the teaching models of EE courses, taking advantage of secondary sources, such as the course syllabi. Second, we investigate the relationship between the identified EE teaching models and students' entrepreneurial learning outcomes. To do so, we identify the EE courses attended by the respondents to the 2018 Italian Global University Entrepreneurial Spirit Students' Survey (GUESSS).

Our study offers two main contributions. First, we add to the research on EE by proposing a coding approach for identifying the teaching model of the EE interventions under analysis. Second, we offer a practical contribution to the design of EE programs by illustrating the implications of adopting a specific teaching model on the learning outcomes of the course.

\section{Literature Review}

\subsection{Entrepreneurship Education and Student Entrepreneurship}

Policymakers and scholars are becoming increasingly interested in student entrepreneurship (Meoli et al. 2020; Lackéus 2015), which is defined as a "new venture creation" by university students and recent graduates (Colombo and Piva 2020). There are several reasons behind such interest - ventures created by students (i) have a large economic impact and contribute to job creation (Åstebro et al. 2011); (ii) represent a mechanism for commercialising the knowledge generated within universities (Shah and Pahnke 2014); (iii) develop and commercialise innovative solutions, which address societal needs (Åstebro and Hoos 2021; Hahn 2020; Sieger et al. 2016); and (iv) represent a valuable career option for young people in a time where youth unemployment affects many countries (Roman and Maxim 2017).

It is, therefore, not surprising that more and more universities are designing a university ecosystem (Wright et al. 2017) that supports student entrepreneurship by stimulating 
students' entrepreneurial attitudes and skills, and facilitates venture creation activities (Fyen et al. 2019). In this regard, EE constitutes a central pillar within the university ecosystem for student entrepreneurship (Gibb et al. 2018) in order to motivate and prepare students from different fields and levels of study (Fiore et al. 2019; Souitaris et al. 2007) to pursue venture creation. In fact, recent studies indicate that EE, at least in certain circumstances, could actually lead to university students creating new businesses (Astebro and Hoos 2021; Eesley and Lee 2020; Lyons and Zhang 2018).

Nevertheless, both scholars (Meoli et al. 2020) and policymakers (Lackéus 2020) have largely acknowledged that the benefits of EE are not limited to stimulating venture creation and that the learning outcomes achieved by students through EE offer several advantages for their careers and personal development. In particular, EE provides cognitive (e.g., creativity, problem-solving, collaboration and communication) and non-cognitive skills (e.g., self-confidence, responsibility and autonomy) (Lackéus 2020; Hahn et al. 2017; Karlsson and Moberg 2013). This is useful for preparing students to think outside the box and become successful not only as founders, but also as employees and managers in general (Lackéus 2020; Leitch et al. 2012). This is because companies are becoming increasingly interested in hiring individuals who are predisposed to the identification and concretisation of value creation opportunities (Kuratko et al. 2021; Eesley and Lee 2020). In fact, graduates endowed with entrepreneurial capabilities earn more and are more likely to join start-ups and innovate for their employers (Longva et al. 2020; Roach and Sauermann 2015; O'Connor 2013). They also tend to have higher levels of income, satisfaction, and employability (Kirkwood et al. 2014; Crayford et al. 2012).

For these reasons, the objectives of EE are not limited to pushing students toward venture creation. Entrepreneurship courses present a much more nuanced multiplicity of objectives (Fayolle 2013). These include, among others, teaching the fundamentals of the entrepreneurship phenomenon, creating awareness regarding entrepreneurial careers, providing basic business knowledge, and offering students the opportunity to develop entrepreneurial soft skills and attitudes, such as creativity, problem-solving, risk-taking and proactivity (Nabi et al. 2018; Volery et al. 2013). This variety of objectives is reflected in the numerous different approaches to teaching EE, as discussed in the paragraph below.

\subsection{Heterogeneity in Entrepreneurship Education Teaching Models}

EE programs involve a large variety of audiences, objectives, content, and pedagogical methods (Fayolle and Lassas-Clerc 2006). EE is offered across faculties to students from different educational backgrounds with various socio-demographic characteristics and levels of involvement in the entrepreneurial process (Blenker et al. 2014).

Because of such variety, EE teaching models, which describe the set of principles embraced by educators to articulate their teaching, greatly vary within and among universities (Sansone et al. 2021; Rauch and Hulsink 2015). To classify the different teaching models adopted in EE, Béchard and Grégoire (2005) proposed an analytical framework of three archetypical teaching models (Table 1): the Supply, Demand, and Competence Model.

The Supply Model builds on the objectivist paradigm, which assumes that "there is a reality 'out there' that is independent of human agents" (Béchard and Grégoire 2005, p. 6). Individual learning is hence shaped by the external factors to which the learner is exposed (such as the knowledge possessed and taught by the teacher). According to this premise, students are seen as passive recipients of the content proposed by the teacher. The teacher plays the primary role in the education process, as it is entirely based on his/her knowledge and behaviour. In this regard, this model conceptualises learning as a transfer of knowledge from the teacher to the student through frontal lectures and formal tests. In terms of content, the Supply Model often aims to deliver basic knowledge about the entrepreneurship phenomenon in line with the "education about entrepreneurship" paradigm (Gibb 1993; Heinonen and Hytti 2010) rather than preparing students to actually engage in real entrepreneurial activities. 
Table 1. Teaching models framework adapted from Béchard and Grégoire's (2005) analytical framework.

\begin{tabular}{|c|c|c|c|}
\hline & \multicolumn{3}{|c|}{ Teaching Models } \\
\hline & Supply Model & Demand Model & Competence Model \\
\hline Philosophical Paradigm & Objectivist & Subjectivist & Interactionist \\
\hline Acquired Knowledge & Knowledge is theoretical & $\begin{array}{l}\text { Knowledge is based on } \\
\text { student's demand of topics }\end{array}$ & $\begin{array}{l}\text { Knowledge is acquired in } \\
\text { practical ways; students are } \\
\text { the central driver of lessons }\end{array}$ \\
\hline Focus & $\begin{array}{l}\text { Transmission of information, } \\
\text { knowledge and theoretical } \\
\text { concepts }\end{array}$ & $\begin{array}{l}\text { Experiential programs and } \\
\text { personalised/participative } \\
\text { methods }\end{array}$ & $\begin{array}{l}\text { Starting up businesses by } \\
\text { consulting external experts } \\
\text { and dealing with real-world } \\
\text { problems }\end{array}$ \\
\hline Teaching Goal & $\begin{array}{l}\text { Remember (retrieve from } \\
\text { memory) and apply (solve } \\
\text { simple problems) }\end{array}$ & $\begin{array}{l}\text { Understand (give meaning) } \\
\text { and analyse (acquire } \\
\text { information and organise } \\
\text { knowledge) }\end{array}$ & $\begin{array}{l}\text { Evaluate (conclude/criticise) } \\
\text { and create (reorganise } \\
\text { knowledge to act), reaching } \\
\text { conclusions and engaging in } \\
\text { critical thinking during tasks }\end{array}$ \\
\hline Method & $\begin{array}{l}\text { Lectures, reading printed } \\
\text { material, watching/listening to } \\
\text { audio-visual documents, } \\
\text { DVDs, etc. }\end{array}$ & $\begin{array}{l}\text { Exploration, interaction, } \\
\text { simulation and discussion }\end{array}$ & $\begin{array}{l}\text { Active problem-solving, } \\
\text { communication, discussion, } \\
\text { debate and seminars }\end{array}$ \\
\hline Contents & $\begin{array}{l}\text { Contents derived from scholarly } \\
\text { research in the entrepreneurship, } \\
\text { management and accounting } \\
\text { disciplines }\end{array}$ & $\begin{array}{c}\text { Contents derived from } \\
\text { student's needs and demand } \\
\text { of topics }\end{array}$ & $\begin{array}{l}\text { Contents derived from } \\
\text { student's projects and } \\
\text { student's problems to solve }\end{array}$ \\
\hline Role of Student & Student as passive learner & Student as active participant & $\begin{array}{l}\text { Student as active participant, } \\
\text { interactivity with teacher }\end{array}$ \\
\hline Role of Teacher & Teacher as presenter & Teacher as tutor and facilitator & Teacher as coach or developer \\
\hline Evaluation & Summative & Formative and summative & $\begin{array}{l}\text { Performance in authentic } \\
\text { situations }\end{array}$ \\
\hline
\end{tabular}

In contrast, the Demand Model builds on the subjectivist paradigm, which assumes that "reality must be understood from the point of view of human agents" (Béchard and Grégoire 2005, p. 7). Therefore, individual learning is primarily driven by individuals' internal factors (i.e., personal factors, such as learners' knowledge, affects, emotions, and goals). From this perspective, education plays the role of promoting the growth of the individual in terms of both knowledge and personal development and, thus, focuses on students' needs and their demand for content. The main implication of this paradigm is that students are not treated as passive actors but as active participants in the educational process.

This model is based on experiential learning and personalised/participative methods through exploration, interactive searches, simulation, discussion, and experimentation. In this case, if the students are considered active participants, the teachers act as tutors and facilitators who guide the students along their learning path. Through the interaction between the students and teachers, the courses' contents emerge based on the students' needs and their demand for topics. This model is in line with the "education for entrepreneurship" paradigm (Gibb 1993; Heinonen and Hytti 2010) and aims at developing students' entrepreneurial skills and attitudes through practical exercises and laboratories of idea generation and validation (Lackéus 2015).

Finally, the Competence Model builds on the interactionist paradigm, which assumes that "reality is both influencing and influenced by the human agency" (Béchard and Grégoire 2005, p. 8). Here, individual learning influences and is influenced by both internal and external factors. In this model, students are engaged in different activities related to the entrepreneurial process: they consult external experts or deal with real-world problems or 
opportunities and are challenged by active problem-solving through communication and discussions. Students lead their learning process, while teachers assume the role of coaches and mentors who support students during their projects. As a result, content is derived from students' projects and the problems they face during their journey. The Competence Model is in line with the "education through entrepreneurship" paradigm (Hannon 2005) and prepares students to engage in entrepreneurial activities.

The above description of the three models of teaching is accurate and quite rigid in the definition of their archetypal characteristics, but it does not necessarily fully capture the variety in real-world educational courses. To extend the boundaries of the three categories and find a better fit for several programs, two hybrid models have been defined in the literature (Béchard and Grégoire 2005): the Supply-Demand and Demand-Competence Models. Both of these combine the peculiar features of their corresponding main archetypes. The hybridisation of two pure models is usually undertaken when the educator perceives that a pure model does not adequately fit the learning needs of the course participants.

\subsection{Entrepreneurship Education Teaching Models and Learning Outcomes}

Despite the conceptual merit of Béchard and Grégoire's (2005) analytical framework of teaching models, scholars lament that we still know little about teaching models' implications on the impact of EE (Nabi et al. 2017). This gap is particularly urgent for both theoretical and empirical reasons if we consider the impact of EE on students' entrepreneurial learning.

From a theoretical perspective, the multidimensional nature of entrepreneurial learning (Hahn et al. 2017; Souitaris et al. 2007) complicates the understanding of which model works better. Entrepreneurial learning outcomes combine the acquisition of business knowledge, soft skills, and motivation toward entrepreneurship (Lautenschläger and Haase 2011). On the one hand, the practice- and experiential-based methods implemented in the Demand and Competence Models seem to be more suitable for developing students' entrepreneurial skills (Hahn et al. 2017; Piperopoulos and Dimov 2015).

Learner-centric approaches require learners to take full responsibility of their learning processes (McNally et al. 2020), which motivates students to put their soft skills into practice by directly experiencing entrepreneurship (Lautenschläger and Haase 2011; Neck and Greene 2011). On the other hand, the merits of the theoretically oriented methods implemented in the Supply Model have been recently highlighted in scholarly debate (Hägg and Kurczewska 2019). Frontal lectures, for example, are useful for imparting entrepreneurship fundamentals and basic knowledge about business and management to students who are not yet mature enough and/or motivated to govern their own learning process and actively participate and learn from practice-oriented entrepreneurial activities. In sum, both theory-oriented and practice-oriented teaching models could have a place in EE (Hägg and Kurczewska 2019).

However, from an empirical standpoint, the extant EE impact research has been largely silent about the effects of specific teaching methods on students' entrepreneurial learning outcomes (Naia et al. 2014). This is because only a few studies (Padilla-Angulo et al. 2021; Sansone et al. 2021) classify the teaching model of EE courses when they assess their impact on entrepreneurial outcomes. Since the design of teaching models has been proven to be crucial for the effectiveness of EE offerings (Åstebro and Hoos 2021), the community of EE scholars would greatly benefit from applying tools and approaches that allow the classification of EE courses into one of the five teaching models defined by Béchard and Grégoire's (2005) analytical framework. The operationalisation of teaching models is urgently required to address the lack of adequate description of the programs and courses assessed in most EE impact studies (Carpenter and Wilson 2021; Yi and Duval-Couetil 2021). In fact, this lack of adequate description severely limits our understanding of the circumstances in which EE is actually effective and could be a substantial reason for the contradictory findings in EE impact research (Nabi et al. 2017). To tackle this challenge, in this study, we develop and implement a coding approach to classify the EE offerings 
attended by students of our sample into one of the five teaching model archetypes. We also explore the extent to which the adoption of a specific teaching model affects entrepreneurial learning outcomes.

\section{Method}

The empirical analysis of this research is based on a sample of Italian university students who participated in the 2018 Global University Entrepreneurial Spirit Students' Survey (GUESSS) ${ }^{1}$. GUESSS is an international research project-coordinated by the Swiss Research Institute of Small Business and Entrepreneurship at the University of St. Gallen and the University of Bern in Switzerland-that collects data through an online student survey, which is carried out every two or three years. In Italy, the survey is coordinated by the Center for Young and Family Enterprise (CYFE) of the University of Bergamo; under such coordination, partner universities' representatives administer the questionnaire to their university's students through different channels (including mailing lists, Facebook groups and social media, etc.). Respondents span different fields of study and education levels. The global data collection process that was carried out in 2018 involved the participation of 54 countries, and over 208,000 responses were gathered from over 3000 universities. The sample has been checked for non-response bias by Hahn et al. (2021a). As for the Italian context, the sample includes around 7299 respondents from 21 universities.

\subsection{Sample}

To proceed with the analysis, out of the 7299 respondents, we selected those who have attended an entrepreneurship course. First, we excluded those respondents who declared they have never attended entrepreneurship courses during their studies. Second, we identified the specific course attended by the remaining students through a section of the questionnaire that asks for further details about the course (i.e., elective vs. compulsory course, name of the course and name of the instructor). We found the specific course they attended using the information that the respondents explicitly provided about the name of the course and the instructor. Taking advantage of this information, we verified that the courses actually mirrored the definition of EE using the universities' websites. More specifically, only those courses that had a specific reference to entrepreneurship, business creation or opportunity generation and development were considered EE offerings. For example, some of the keywords for the course descriptions are "entrepreneurship", "business planning", "start-ups", and "innovation".

The word "entrepreneurship" has been found in the name of most courses, but, in some cases, it was found only in the course's description. Learning how to recognise and exploit a business opportunity and develop an effective business model are the core elements of entrepreneurship courses: this is the reason why we detected "start-ups" and "business planning" as crucial keywords. These terms appeared in 70\% and 62\%, respectively, of the courses analysed in this study. Finally, "innovation" is another recurring keyword and is used for $62 \%$ of the courses. If the indicated courses did not qualify as entrepreneurship courses after the analysis of their syllabus, we excluded the corresponding respondents from our sample. Further, 126 respondents did not provide additional details about the course they attended even though they claimed to have participated in EE. For such cases, we used their education data (e.g., university, field of study, level of study and year of the start of studies) to identify their classmates in the sample. Using the information provided by the classmates of these 126 respondents, we were then able to identify the specific EE course that they attended. After these steps, the resulting sample consisted of 386 students matched with 42 different courses from 16 universities $^{2}$.

\subsection{Research Method}

To explore the relationship between different EE teaching models and the students' entrepreneurial learning outcomes, we adopted the following research method. As a first 
step, we classified the teaching models of the EE courses attended by the students in our sample through the coding of the courses' syllabi. Next, we investigated the relationship between the different types of EE teaching models adopted in the courses and the learning outcomes reported by the students. To do so, we adopted a multiple regression framework, as conventionally done in EE impact studies (cf. Hahn et al. 2017, 2020); by estimating the coefficients, this approach evaluates the impact of different teaching models on learning outcomes. The goal of this analysis is to determine whether certain approaches are more effective than others in stimulating students' entrepreneurial learning. More specifically, in line with prior EE impact studies (e.g., Hahn et al. 2017), we used Hierarchical regression analysis (Cohen and Cohen 1983), which involves building successive linear regression models - each containing additional predictors. As our data are individual-level observations nested within universities, we took advantage of the clustered standard errors approach in all our models, as done in previous studies based on GUESSS data (cf. Hahn 2020; Hahn et al. 2020; Minola et al. 2016). We selected the GUESSS database because it is an internationally recognised project in the academic community that involves a large number of university students and has generated a variety of peer-reviewed publications in top-level journals ${ }^{3}$. Specifically, it provides detailed information about the studies of the respondents, especially with regard to EE, and the entrepreneurial learning that students attribute to the university offerings.

\subsection{Classification of the Teaching Models}

After identifying the specific courses attended by the respondents in our final sample, we classified them according to the five models (Supply, Demand, Competence, and the two hybrids) defined by Béchard and Grégoire (2005). To do so, two of the authors separately conducted an in-depth analysis of the courses' descriptions on the university webpages. In cases of disagreement, after a discussion together with the third author, we agreed on the coding of the course teaching model.

In particular, the classification has been implemented following the scheme shown in Table 2, which was adapted from Béchard and Grégoire's (2005) teaching models framework. We read the full syllabus of each course to search for keywords or expressions that would indicate the specific teaching model of the courses. Each keyword or expression was assigned an identification code: "S" to indicate the Supply Model, "SD" for the Supply-Demand Model, "D" for the Demand Model, "DC" for the Demand-Competence Model, " $\mathrm{C}$ " for the Competence Model. The presence of the keywords or expressions that mirrored the teaching model's characteristics was not a sine qua non; in fact, as the courses' syllabi were not written using a vocabulary that had been standardised according to our classification rules, we also considered the context in which those keywords were expressed when classifying the teaching models. Next, a mode analysis was carried out to define the final classification of the teaching model of the course. 
Table 2. Classification scheme and keywords for teaching models.

\begin{tabular}{|c|c|c|c|c|c|}
\hline & $\begin{array}{l}\text { Supply } \\
\text { Model } \\
\text { "S" }\end{array}$ & $\begin{array}{c}\text { Supply-Demand } \\
\text { Model } \\
\text { "SD" }\end{array}$ & $\begin{array}{l}\text { Demand } \\
\text { Model } \\
\text { "D" }\end{array}$ & $\begin{array}{c}\text { Demand- } \\
\text { Competence } \\
\text { Model } \\
\text { "DC" }\end{array}$ & $\begin{array}{l}\text { Competence } \\
\text { Model } \\
\text { "C" }\end{array}$ \\
\hline Focus & Teacher needs & $\begin{array}{c}\text { Teacher-student } \\
\text { needs }\end{array}$ & Student needs & $\begin{array}{l}\text { Student needs and } \\
\text { relationship }\end{array}$ & $\begin{array}{l}\text { Student/teacher } \\
\text { relationship }\end{array}$ \\
\hline Role of Teacher & Educator/presenter & Educator/tutor & Tutor/facilitator & Tutor/mentor & Coach/developer \\
\hline Role of Student & Passive recipients & $\begin{array}{l}\text { Passive-active } \\
\text { participants }\end{array}$ & Active participants & $\begin{array}{c}\text { Active-interactive } \\
\text { participants }\end{array}$ & $\begin{array}{l}\text { Interactive } \\
\text { participants }\end{array}$ \\
\hline Content & Abstract & $\begin{array}{c}\text { Abstract- } \\
\text { contextualised }\end{array}$ & Contextualised & $\begin{array}{l}\text { Contextualised- } \\
\text { experiential }\end{array}$ & Experiential \\
\hline Method & $\begin{array}{l}\text { Frontal lectures, } \\
\text { readings }\end{array}$ & $\begin{array}{l}\text { Frontal lectures, } \\
\text { discussion }\end{array}$ & $\begin{array}{c}\text { Exploration, } \\
\text { interaction, } \\
\text { discussion through } \\
\text { experimentations }\end{array}$ & $\begin{array}{l}\text { Discussion, } \\
\text { simulations }\end{array}$ & $\begin{array}{c}\text { Active } \\
\text { problem-solving, } \\
\text { communication, } \\
\text { discussion, debate, } \\
\text { seminar through } \\
\text { simulations }\end{array}$ \\
\hline $\begin{array}{c}\text { Acquired } \\
\text { Knowledge }\end{array}$ & Theoretical & $\begin{array}{c}\text { Theoretical- } \\
\text { practical }\end{array}$ & $\begin{array}{c}\text { Theoretical and } \\
\text { practical }\end{array}$ & $\begin{array}{c}\text { Practical- } \\
\text { experimental }\end{array}$ & Experimental \\
\hline Teaching Goal & $\begin{array}{l}\text { Remember and } \\
\text { apply to solve } \\
\text { simple problems }\end{array}$ & $\begin{array}{l}\text { Remember and } \\
\text { understand }\end{array}$ & $\begin{array}{c}\text { Understand } \\
\text { information and } \\
\text { analyse it }\end{array}$ & $\begin{array}{l}\text { Understand and } \\
\text { engage in critical } \\
\text { thinking }\end{array}$ & $\begin{array}{c}\text { Evaluate and reach } \\
\text { conclusions } \\
\text { through critical } \\
\text { thinking }\end{array}$ \\
\hline
\end{tabular}

The following case outlines an example of our classification procedure:

- Name of the course: Contamination Lab Bergamo-Healthcare CLab (HC.LAB) (Hahn et al. 2021b)

- Affiliation: University of Bergamo

- Description: During the HC.LAB path, the development of the entrepreneurial culture will be achieved through thematic in-depth analysis and the development of dedicated projects. The ultimate goal of HC.LAB is to introduce students to the themes and tools of innovative entrepreneurship applied to the healthcare industry. The training program provides for the involvement of participants through various tools, such as frontal teaching activities and specialised seminars, both in the classroom and remotely, access to recorded material and reference literature and laboratory activities. These methods may also vary depending on the provisions of the authorities and the University regarding public safety and health through forms of active participation both in frontal mode and in the laboratories, experimental and design modes. In particular, the HC.LAB course is divided into five macro-modules, the structure and duration of which are reported below:

1. Macro-module $1(8 \mathrm{~h})$ : Introduction to entrepreneurship, entrepreneurship as a lever for innovation and change, cases of innovative entrepreneurship in the health sector.

2. Macro-module $2(12 \mathrm{~h})$ : Scenarios and innovation needs for the ageing population, interventions by experts in the sector, scenario analysis, identification of needs.

3. Macro-module 3 ( $12 \mathrm{~h}$ ): Tools and methodologies to support the entrepreneurial project, idea generation, need analysis through empathy map, business model analysis through Business Model Canvas.

4. Macro-module $4(16 \mathrm{~h})$ : Training of the project teams and elaboration of the project, brief project presentation, project development, mentorship with faculty and partners. 
5. Macro-module $5(12 \mathrm{~h})$ : Validation and evaluation of the solution identified and of the project as a whole, interviews and surveys with the stakeholders of business projects, evaluation of the projects by the faculty and partners.

The overall duration of the course was $60 \mathrm{~h}$, including all activities, in the relative modalities (in person, online, recorded teaching material, etc.) and the tutoring and mentoring sessions for the validation of the projects.

Considering the above course description and, particularly, the keywords indicated in bold in the text above, we classified the HC.LAB's teaching model through an in-depth syllabus analysis (cf. Table 2 for the classification scheme) ${ }^{4}$ :

- Focus: The relationship between student and teacher promotes the learning process ("active participation both in frontal mode and in the laboratories, experimental and design modes"). According to this quote, the corresponding teaching model is the Competence Model (identification code: $\mathrm{C}$ ).

- Role of Teacher: The teacher is both a tutor and a mentor ("tutoring and mentoring sessions"). The teaching model in which the teacher is both a tutor and a mentor is the Demand-Competence Model (identification code: DC).

- Role of Student: Active participation by students is required in the course. In fact, students should be both active during lectures and interactive during laboratory sessions ("active participation both in frontal mode and the laboratories, experimental and design modes"). For this reason, the teaching model is the Demand-Competence Model (identification code: DC).

- Contents: In the HC.LAB course, students define needs and problems to solve ("Scenarios and innovation needs for the ageing population, interventions by experts in the sector, scenario analysis, identification of needs"). The course's contents are derived from students' projects and students' problems or questions to solve: hence contents are considered experiential. The corresponding teaching model is the Competence Model (identification code: $\mathrm{C}$ ).

- Method: Lectures are conducted as discussions and simulations of businesses ("frontal teaching activities and specialised seminars both in the classroom and remotely, access to recorded material and reference literature and laboratory activities"). Considering the method of the course, it is based on discussions and simulations. Thus, the corresponding teaching model is the Demand-Competence Model (identification code: DC).

- Acquired Knowledge: The course is divided into five macro-modules that deliver the content both theoretically and practically. The acquired knowledge is both theoretical (modules 1 and 2) and experimental (modules 3, 4 and 5). For this reason, the corresponding teaching model is the Demand-Competence Model (identification code: DC).

- Educational Goal: The educational goal of the course is to introduce students to the themes and tools of entrepreneurship applied to a specific industry ("to introduce students to the themes and tools of innovative entrepreneurship applied to the healthcare industry"). In this case, the educational goal is based on understanding and critical thinking; thus, the teaching model is Demand-Competence Model (identification code: $\mathrm{DC})$.

Below, we report the summary of the classification necessary for the next phase, which is based on the mode as a criterion for the final classification of the teaching model (cf. Table 2 for the classification scheme):

- $\quad$ Focus: Relationship between tutors and students $\rightarrow \mathbf{C}$

- $\quad$ Role of Teacher: Tutor-mentor $\rightarrow$ DC

- Role of Student: Active-interactive $\rightarrow$ DC

- Contents: Experiential $\rightarrow \mathrm{C}$

- Method: Discussion-simulations $\rightarrow$ DC

- $\quad$ Acquired Knowledge: Theoretical-experimental $\rightarrow$ DC 
- $\quad$ Educational Goal: Understand-critical thinking $\rightarrow$ DC

Finally, we used the mode resulting from the analysis to classify the course's teaching model.

- Mode: "DC"

- Teaching model: Demand-Competence Model (identification code: DC).

The coding process described previously was repeated for all the EE courses included in the sample; the outcome of the coding process is reported in Table 3.

Table 3. Breakdown of courses by teaching models.

\begin{tabular}{|c|c|c|c|}
\hline University & Courses & No. of Students & Teaching Model \\
\hline \multirow{7}{*}{$\begin{array}{l}\text { Politecnico di Torino } \\
\text { (6 courses) }\end{array}$} & $\begin{array}{l}\text { Alta Scuola Politecnica-School of } \\
\text { Entrepreneurship and Innovation (High } \\
\text { Polytechnic School) }\end{array}$ & 12 & Competence \\
\hline & Contamination Lab Torino (a) & 18 & Demand-Competence \\
\hline & European Innovation Academy & 2 & Competence \\
\hline & $\begin{array}{l}\text { Imprenditorialità e Innovazione } \\
\text { (Entrepreneurship and Innovation) }\end{array}$ & 34 & Supply-Demand \\
\hline & $\begin{array}{l}\text { Imprenditorialità e Business Planning } \\
\text { (Entrepreneurship and Business Planning) }\end{array}$ & 10 & Demand \\
\hline & $\begin{array}{l}\text { Intellectual Property Rights, Technology } \\
\text { Transfer and Hi-tech Entrepreneurship }\end{array}$ & 1 & Supply \\
\hline & Total & 77 & \\
\hline \multirow{2}{*}{$\begin{array}{l}\text { Università degli Studi della } \\
\text { Campania Luigi Vanvitelli } \\
\text { (1 course) }\end{array}$} & Digita Academy & 1 & Competence \\
\hline & Total & 1 & \\
\hline \multirow{7}{*}{$\begin{array}{l}\text { Università degli studi di } \\
\text { Bergamo } \\
(6 \text { courses })\end{array}$} & Contamination Lab Bergamo (HC.LAB) & 8 & Demand-Competence \\
\hline & $\begin{array}{l}\text { Economia del Cambiamento Tecnologico } \\
\text { (Economics of Technological Change) }\end{array}$ & 11 & Demand \\
\hline & Entrepreneurship Bootcamp & 7 & Competence \\
\hline & Humanities Summer School ("Make in Italy") & 3 & Demand \\
\hline & $\begin{array}{l}\text { Imprenditorialità e Private Equity } \\
\text { (Entrepreneurship and Private Equity) }\end{array}$ & 1 & Demand \\
\hline & $\begin{array}{l}\text { Imprenditorialità, Innovazione e Marketing } \\
\text { (Entrepreneurship, Innovation and Marketing) }\end{array}$ & 2 & Demand \\
\hline & Total & 32 & \\
\hline \multirow{3}{*}{$\begin{array}{l}\text { Università degli studi di } \\
\text { Modena e Reggio Emilia } \\
\text { ( } 2 \text { courses })\end{array}$} & Contamination Lab Modena & 8 & Demand-Competence \\
\hline & Web Usability & 1 & Supply \\
\hline & Total & 9 & \\
\hline \multirow{2}{*}{$\begin{array}{l}\text { Università degli Studi di } \\
\text { Roma "Tor Vergata" } \\
(1 \text { course })\end{array}$} & $\begin{array}{l}\text { Economia e Gestione dell'Innovazione (a) } \\
\text { (Economics and Management of Innovation) }\end{array}$ & 2 & Demand \\
\hline & Total & 2 & \\
\hline \multirow{2}{*}{$\begin{array}{l}\text { Università degli Studi di } \\
\text { Salerno } \\
(1 \text { course })\end{array}$} & Digita Academy & 2 & Competence \\
\hline & Total & 2 & \\
\hline \multirow{2}{*}{$\begin{array}{l}\text { Università degli Studi di } \\
\text { Sassari } \\
(1 \text { course })\end{array}$} & Contamination Lab Sassari & 4 & Demand-Competence \\
\hline & Total & 4 & \\
\hline
\end{tabular}


Table 3. Cont.

\begin{tabular}{|c|c|c|c|}
\hline University & Courses & No. of Students & Teaching Model \\
\hline \multirow{4}{*}{$\begin{array}{l}\text { Università degli Studi di Siena } \\
\text { ( } 3 \text { courses })\end{array}$} & $\begin{array}{l}\text { Business Planning e Start-up d'Impresa } \\
\text { (Business Planning and Business Start-up) }\end{array}$ & 1 & Supply \\
\hline & Contamination Lab Siena & 2 & Demand-Competence \\
\hline & Entrepreneurship and Innovation Management & 14 & Supply \\
\hline & Total & 17 & \\
\hline \multirow{2}{*}{$\begin{array}{l}\text { Università degli studi di } \\
\text { Trento } \\
\text { (1 course) }\end{array}$} & International Entrepreneurship & 1 & Demand-Competence \\
\hline & Total & 1 & \\
\hline \multirow{4}{*}{$\begin{array}{l}\text { Università degli Studi di } \\
\text { Trieste } \\
(3 \text { courses })\end{array}$} & Applied Neurosciences & 1 & Supply \\
\hline & Contamination Lab Trieste & 12 & Demand-Competence \\
\hline & Intellectual Property Rights & 1 & Supply-Demand \\
\hline & Total & 14 & \\
\hline \multirow{2}{*}{$\begin{array}{l}\text { Università degli Studi di } \\
\text { Urbino "Carlo Bo" } \\
(1 \text { course })\end{array}$} & Contamination Lab Urbino & 4 & Demand-Competence \\
\hline & Total & 4 & \\
\hline \multirow{6}{*}{$\begin{array}{l}\text { Università degli Studi di } \\
\text { Verona } \\
(5 \text { courses })\end{array}$} & Business Plan and Fund Raising & 1 & Supply-Demand \\
\hline & Ceriecon Interreg Europe & 2 & Competence \\
\hline & Contamination Lab Veneto & 8 & Demand-Competence \\
\hline & $\begin{array}{l}\text { Fondamenti di Management (Fundamentals of } \\
\text { Management) }\end{array}$ & 10 & Supply \\
\hline & $\begin{array}{l}\text { Management e Comunicazione per le Piccole e } \\
\text { Medie Imprese (Management and } \\
\text { Communication for Small and Medium } \\
\text { Enterprises) }\end{array}$ & 22 & Supply \\
\hline & Total & 43 & \\
\hline \multirow{2}{*}{$\begin{array}{l}\text { Università del Salento } \\
(1 \text { course })\end{array}$} & Contamination Lab Salento & 2 & Demand-Competence \\
\hline & Total & 2 & \\
\hline \multirow{2}{*}{$\begin{array}{l}\text { Università della Calabria } \\
\text { (1 course) }\end{array}$} & Contamination Lab Calabria & 35 & Demand-Competence \\
\hline & Total & 35 & \\
\hline \multirow{6}{*}{$\begin{array}{l}\text { Università di Napoli } \\
\text { Federico II } \\
\text { ( } 5 \text { courses })\end{array}$} & Contamination Lab Napoli & 13 & Demand-Competence \\
\hline & Creazione d'Impresa (Business Creation) & 1 & Supply \\
\hline & Digita Academy & 8 & Competence \\
\hline & $\begin{array}{l}\text { Gestione dello Sviluppo Imprenditoriale } \\
\text { (Business Development Management) }\end{array}$ & 23 & Demand \\
\hline & Mind the Bridge Startup School & 1 & Competence \\
\hline & Total & 46 & \\
\hline
\end{tabular}


Table 3. Cont.

\begin{tabular}{|c|c|c|c|}
\hline University & Courses & No. of Students & Teaching Model \\
\hline \multirow{8}{*}{$\begin{array}{l}\text { Università di Torino } \\
\text { (7 courses) }\end{array}$} & Contamination Lab Torino (b) & 25 & Demand-Competence \\
\hline & $\begin{array}{l}\text { Diventare Imprenditori (Becoming } \\
\text { Entrepreneurs) }\end{array}$ & 47 & Supply \\
\hline & $\begin{array}{l}\text { Economia e Gestione dell'Innovazione (b) } \\
\text { (Economics and Management of Innovation) }\end{array}$ & 7 & Demand \\
\hline & Entrepreneurship & 5 & Demand-Competence \\
\hline & European Innovation Academy & 2 & Competence \\
\hline & $\begin{array}{l}\text { Principi di Redazione del Business Plan } \\
\text { (Principles for drafting the Business Plan) }\end{array}$ & 10 & Supply-Demand \\
\hline & Startup Creation Lab & 1 & Competence \\
\hline & Total & 97 & \\
\hline
\end{tabular}

Note: We report the English translation of the names of the courses taught in Italian in brackets. The sum of the number of courses exceeds 42 because the "Digita Academy" course welcomes students of our sample from 3 different universities (Università degli Studi della Campania Luigi Vanvitelli, Università degli Studi di Salerno and Università di Napoli Federico II), and the "European innovation academy" course welcomes students of our sample from two different universities (Politecnico di Torino and Università di Torino); therefore, these courses are counted multiple times.

Of the 42 courses, 9 (21\%) reflected the Supply Model, $4(10 \%)$ reflected the SupplyDemand Model, 8 (19\%) indicated the Demand Model, 14 (33\%) indicated the DemandCompetence Model, and 7 (17\%) reflected the Competence Model.

Table 4 provides an overview of the distribution of the courses among teaching models and faculties. Entrepreneurial courses based on the Supply Model are spread among various faculties, typically with the aim of providing a basic understanding of the entrepreneurship phenomenon (Arasti et al. 2012). Courses based on the DemandCompetence and the Competence Models are generally cross-disciplinary. They usually include elective activities, carried out parallel to the curricula, that allow students to experience the entrepreneurial process in a supportive environment and develop their business ideas.

Table 4. Distribution of courses according to teaching models and faculties.

\begin{tabular}{lcccc}
\hline \multicolumn{1}{c}{ Field of Study } & $\begin{array}{c}\text { Cross- } \\
\text { Disciplinary }\end{array}$ & $\begin{array}{c}\text { Business, } \\
\text { Management, } \\
\text { Economics }\end{array}$ & $\begin{array}{c}\text { Other (Natural } \\
\text { and Social } \\
\text { Sciences) }\end{array}$ & $\begin{array}{c}\text { Total } \\
\text { Supplying Model }\end{array}$ \\
Supply-Demand & 4 & 2 & 3 & $\mathbf{9}$ \\
Demand & 2 & 1 & 1 & 4 \\
Demand-Competence & 12 & 3 & 4 & $\mathbf{8}$ \\
Competence & 5 & -1 & 2 & $\mathbf{1 4}$ \\
\hline Total & $\mathbf{2 4}$ & $\mathbf{7}$ & $\mathbf{1 1}$ & $\mathbf{4 2}$ \\
\hline
\end{tabular}

In terms of the number of students (Table 5), most students in the sample are undergraduates $(253 ; 66 \%)$. Of these, $95(25 \%)$ attended an EE Demand-Competence Model course, and 74 attended an EE Supply Model course (19\%). Compared to the undergraduate students, the graduate students in the sample were found to be more likely to have experienced practice-oriented teaching models, which are typically better suited for more mature students (Hägg and Kurczewska 2019). 
Table 5. Distribution of respondents according to teaching models and levels of study.

\begin{tabular}{lccccc}
\hline Level of Study & Undergrad. & Graduate & $\begin{array}{c}\text { Other (PhD } \\
\text { and MBA) }\end{array}$ & $\begin{array}{c}\text { Not } \\
\text { Specified }\end{array}$ & Total \\
\hline Teaching Model & 74 & 23 & 1 & - & $\mathbf{9 8}$ \\
Supply & 46 & - & - & - & 46 \\
Demand & 26 & 32 & 1 & - & 59 \\
Demand-Competence & 95 & 44 & 4 & 2 & $\mathbf{1 4 5}$ \\
Competence & 12 & 25 & 1 & - & 38 \\
\hline Total & $\mathbf{2 5 3}$ & $\mathbf{1 2 4}$ & $\mathbf{7}$ & $\mathbf{2}$ & 386 \\
\hline
\end{tabular}

Finally, Table 6 breaks down EE teaching models based on their elective vs. compulsory nature.

Table 6. Distribution of courses according to types of courses and teaching models.

\begin{tabular}{lccc}
\hline \multicolumn{1}{c}{ Type of Course } & Compulsory & Elective & Total \\
Teaching Model & 7 & 2 & 9 \\
\hline Supply & 2 & 2 & 4 \\
Supply-Demand & 6 & 2 & 8 \\
Demand & 1 & 13 & $\mathbf{1 4}$ \\
Demand-Competence & 1 & 6 & 7 \\
Competence & $\mathbf{1 7}$ & $\mathbf{2 5}$ & $\mathbf{4 2}$ \\
\hline Total & & & \\
\hline
\end{tabular}

Most of the courses were elective $(25 ; 60 \%)$, and the rest were compulsory $(17 ; 40 \%)$. Most practice-oriented courses (Demand-Competence and Competence Models) were elective courses, as they are typically designed for students who are highly interested in experiencing and learning about entrepreneurship (Hägg and Kurczewska 2019). In contrast, compulsory courses are often aimed at providing knowledge about entrepreneurship to students using more traditional lecturing methods (Hahn et al. 2020).

To perform the analysis, we examined the data for missing values: 10 out of 386 (about $3 \%$ of the sample) did not answer the question needed to build the variable of interest (the dependent variable). After filtering out the respondents for whom we could not build the variable of interest, the final sample used for the multivariate analyses consisted of 376 students.

\subsection{Measures}

Dependent variable. We measured learning outcomes (LO) using the entrepreneurial learning scale defined by Souitaris et al. (2007). It is a five-item, 7-point Likert scale that captures the entrepreneurial knowledge, attitudes and skills that the students acquired through university offerings. The items of the scale are as follows: (1) "increased my understanding of the attitudes, values and motivation of entrepreneurs"; (2) "increased my understanding of the actions someone has to take to start a business"; (3) "enhanced my practical management skills to start a business"; (4) "enhanced my ability to develop networks"; and (5) "enhanced my ability to identify an opportunity". The reliability of the scale was tested by computing the Cronbach's alpha, which resulted in 0.91, which is above the recommended value of 0.7 (Nunnally 1978). The scores of the five items were thus averaged to compute the dependent variable, LO.

Independent variables. To measure the teaching model associated with the EE attended by each student, we created five different dummy variables (one for each teaching model): S for Supply, SD for Supply-Demand, D for Demand, DC for Demand-Competence and $\mathrm{C}$ for Competence. Each dummy takes the value of 1 if the EE course attended by the respondent belongs to the specific teaching model associated with that dummy (otherwise, its value is 0 ). 
Control variables. We control for a set of demographic and student-related variables, which is in line with extant EE impact studies (e.g., Hahn et al. 2017, 2020). As men tend to be more confident in their entrepreneurial skills, we controlled for gender, which was coded with a dummy variable where 0 indicates male and 1 indicates female. We control for students' education level of study by creating the dummy variable named Undergraduate (equal to 1 for undergraduate students; otherwise, 0 ). We also control for students' prior exposure to entrepreneurship in their families, as this might affect their learning from EE (Hahn et al. 2020). To do this, we created the dummy variable named Parent Entrepreneurship, which is equal to 1 if at least one of the individual's parents is self-employed (otherwise, $0)$. Finally, we introduce the dummy variable named Business, Management, Economics (BME) (equal to 1 if the respondent belongs to disciplinary areas related to management, business or economics; otherwise, 0 ). Despite the growing importance of EE in all university departments, students enrolled in business, management and economics study plans place more emphasis on learning entrepreneurship; it might increase their confidence in their knowledge to develop and lead firms and, thus, affect the LO (Hahn et al. 2017).

\section{Results}

The mean values, standard deviations and statistical correlations are reported in Table 7 , while Table 8 displays the descriptive statistics of the sample divided according to teaching models. The means reported in Table 8 show that $25 \%$ of the students in the sample took EE in Supply Model, 12\% took EE in Supply-Demand Model, 16\% in Demand Model, 37\% in Demand-Competence Model, and 10\% in Competence Model. To assess multicollinearity, we computed the variance inflation factors to quantify how inflated the variance is. All the VIF values remained below 5, with an average of 1.02, which indicates that multicollinearity is not a problem in the analyses (Kennedy 2008). Table 9 reports the hierarchical OLS regression used to test the relationship between EE teaching models and LO.

To facilitate the interpretation of the regression coefficients, the dependent variable has been standardised. Model 1 assumes LO as the dependent variable and contains only control variables; in particular, the field of study BME is positive and significant, which suggests that studying in business, management and economics is associated with higher entrepreneurial LO. In model 2, the independent variables Supply-Demand, Demand, Demand-Competence and Competence Models are entered, except for the Supply variable, which is used as the reference group. All the models considered in the regression lead to a positive impact on LO as compared to the Supply Model. However, while the effect of Supply-Demand $(\beta=0.1931, p<0.05)$, Demand $(\beta=0.3270, p<0.01)$ and DemandCompetence $(\beta=0.3730, p<0.05)$ are statistically significant, the coefficient associated with the Competence Model is not.

These results indicate that students who attended EE courses based on the SupplyDemand, Demand or Demand-Competence Model report higher levels of LO compared to those who attended courses that used the Supply Model. More specifically, based on the value of the coefficients, in terms of LO, they obtained an advantage of about 0.2 standard deviations of LO from the Supply-Demand Model, of about 0.3 from the Demand Model and of 0.4 from the Demand-Competence Model. 
Table 7. Descriptive statistics and correlations.

\begin{tabular}{|c|c|c|c|c|c|c|c|c|c|c|c|c|}
\hline Variables & Mean & St. Dev. & (1) & (2) & (3) & (4) & (5) & (6) & (7) & (8) & (9) & (10) \\
\hline (1) $\mathrm{LO}$ & 4.55 & 1.41 & 1 & & & & & & & & & \\
\hline (2) Supply & 0.25 & 0.43 & -0.1299 * & 1 & & & & & & & & \\
\hline (3) Supply-Demand & 0.12 & 0.33 & -0.0692 & $-0.2129 *$ & 1 & & & & & & & \\
\hline (5) Demand-Comp. & 0.37 & 0.48 & $0.1315 *$ & $-0.4447^{*}$ & -0.2840 * & -0.3323 * & 1 & & & & & \\
\hline (6) Competence & 0.10 & 0.30 & 0.0059 & $-0.1936^{*}$ & $-0.1236^{*}$ & $-0.1447 *$ & -0.2583 * & 1 & & & & \\
\hline (7) Gender & 0.44 & 0.50 & 0.0034 & $0.2434 *$ & -0.1620 * & 0.0006 & -0.0685 & -0.0662 & 1 & & & \\
\hline (8) Undergraduate & 0.65 & 0.48 & $-0.1113 *$ & 0.1356 * & $0.2680 *$ & -0.1937 * & -0.0069 & $-0.2386^{*}$ & 0.0991 & 1 & & \\
\hline (10) BME & 0.27 & 0.44 & $0.1511 *$ & 0.0242 & -0.2050 * & $-0.1460 *$ & $0.1911 *$ & 0.0506 & -0.0417 & -0.1272 * & -0.0798 & 1 \\
\hline
\end{tabular}

$\mathrm{N}=376$. Absolute values of pairwise correlations above 0.11 are significant at the $*<0.05$ level.

Table 8. Descriptive statistics for the sample divided based on teaching models.

\begin{tabular}{|c|c|c|c|c|c|c|c|c|c|c|}
\hline \multirow[t]{2}{*}{ Variables } & \multicolumn{2}{|c|}{$\begin{array}{l}\text { Supply Model } \\
\quad(\mathbf{N}=94)\end{array}$} & \multicolumn{2}{|c|}{$\begin{array}{l}\text { Supply-Demand Model } \\
\qquad(\mathrm{N}=45)\end{array}$} & \multicolumn{2}{|c|}{$\begin{array}{l}\text { Demand Model } \\
\quad(N=59)\end{array}$} & \multicolumn{2}{|c|}{$\begin{array}{l}\text { Demand-Competence Model } \\
\qquad(\mathrm{N}=140)\end{array}$} & \multicolumn{2}{|c|}{$\begin{array}{l}\text { Competence Model } \\
\quad(N=38)\end{array}$} \\
\hline & Mean & SD & Mean & SD & Mean & SD & Mean & SD & Mean & SD \\
\hline $\mathrm{LO}$ & 4.24 & 1.39 & 4.29 & 1.19 & 4.68 & 1.54 & 4.80 & 1.37 & 4.58 & 1.57 \\
\hline Gender & 0.64 & 0.48 & 0.22 & 0.42 & 0.44 & 0.50 & 0.40 & 0.49 & 0.34 & 0.48 \\
\hline Entr. Parents & 0.40 & 0.49 & 0.44 & 0.50 & 0.29 & 0.46 & 0.41 & 0.49 & 0.37 & 0.49 \\
\hline Undergraduate & 0.77 & 0.42 & 1 & 0 & 0.44 & 0.50 & 0.65 & 0.48 & 0.32 & 0.47 \\
\hline BME & 0.29 & 0.46 & 0.02 & 0.15 & 0.12 & 0.33 & 0.38 & 0.49 & 0.34 & 0.48 \\
\hline
\end{tabular}


Table 9. Main regression analyses.

\begin{tabular}{|c|c|c|}
\hline Independent Variables & $\begin{array}{c}(1) \\
\text { Model } 1\end{array}$ & $\begin{array}{c}(2) \\
\text { Model } 2\end{array}$ \\
\hline Gender & $\begin{array}{c}0.0367 \\
(0.0764)\end{array}$ & $\begin{array}{c}0.0852 \\
(0.0740)\end{array}$ \\
\hline Undergraduate & $\begin{array}{l}-0.2049 \\
(0.1244)\end{array}$ & $\begin{array}{l}-0.1697 \\
(0.1192)\end{array}$ \\
\hline Entr. Parents & $\begin{array}{c}0.0274 \\
(0.0777)\end{array}$ & $\begin{array}{c}0.0285 \\
(0.0821)\end{array}$ \\
\hline BME & $\begin{array}{l}0.3150 * * \\
(0.1115)\end{array}$ & $\begin{array}{l}0.3055^{* *} \\
(0.1222)\end{array}$ \\
\hline Supply-Demand Model & & $\begin{array}{c}0.1931^{* *} \\
(0.0778)\end{array}$ \\
\hline Demand Model & & $\begin{array}{c}0.3270 * * * \\
(0.1071)\end{array}$ \\
\hline Demand-Competence Model & & $\begin{array}{l}0.3730^{* *} \\
(0.1423)\end{array}$ \\
\hline Competence Model & & $\begin{array}{c}0.1761 \\
(0.1170)\end{array}$ \\
\hline Constant & $\begin{array}{c}0.0238 \\
(0.0983)\end{array}$ & $\begin{array}{c}-0.2492 \text { ** } \\
(0.1122)\end{array}$ \\
\hline $\mathrm{R}^{2}$ & 0.0321 & 0.0539 \\
\hline$\Delta \mathrm{R}^{2}$ & & $\begin{array}{c}\text { cf. Model } 1 \\
0.0218\end{array}$ \\
\hline
\end{tabular}

$\mathrm{N}=376$. Supply Model as reference group. Number of groups $=16$ universities. Standard errors in brackets *** $p<0.01,{ }^{* *} p<0.05, * p<0.1$.

We also performed three robustness checks to strengthen our findings. First, we introducing university fixed effects in the analysis to control for unobserved university characteristics that may affect entrepreneurial learning. The results remained mostly unchanged, with the coefficients of the Supply-Demand and Demand-Competence Models being significantly positive, as seen in our main specification. Second, since we sampled only students who have attended EE, who might select themselves in universities or programs that facilitate entrepreneurial learning, we applied a Heckman two-step procedure to mitigate the concern that results might be biased by such sample selection. To do this, we estimated, for the full sample, a probit model on students' probability of not attending EE, using their gender and whether they have entrepreneur parents as independent variables (cf. Hahn 2020). We found that being male and having self-employed parents is significantly and positively associated with the probability of attending EE. Based on these predicted probabilities, we computed the inverse Mill's Ratio and included it in our second-stage equation that assumes $\mathrm{LO}$ as the dependent variable. We verified that, when including this ratio as a control variable, it is not significant and does not affect the results of the main model (Table 10). Hence, self-selection is not a concern. Finally, we verified that the linear regression is more appropriate than the multilevel mixed-effects regression approach, which could also be used when the student data are nested in universities (Hahn et al. 2017). The likelihood ratio test performed after this regression approach indicated that a multilevel regression is not required because the null hypothesis that random effects are equal to 0 could not be rejected. 
Table 10. Heckman two-step procedure.

\begin{tabular}{|c|c|c|}
\hline Variables & $\begin{array}{c}\text { (1) } \\
\text { Model } 1\end{array}$ & $\begin{array}{c}(2) \\
\text { Model } 2\end{array}$ \\
\hline Supply-Demand Model & & $\begin{array}{c}0.174 * \\
(0.0889)\end{array}$ \\
\hline Demand Model & & $\begin{array}{c}0.307^{* * *} \\
(0.104)\end{array}$ \\
\hline Demand-Competence Model & & $\begin{array}{c}0.360 * * \\
(0.138)\end{array}$ \\
\hline Competence Model & & $\begin{array}{c}0.163 \\
(0.116)\end{array}$ \\
\hline Undergraduate & & $\begin{array}{l}-0.163 \\
(0.118)\end{array}$ \\
\hline BME & & $\begin{array}{c}0.293^{* *} \\
(0.130)\end{array}$ \\
\hline Inverse Mills Ratio & & $\begin{array}{l}-1.258 \\
(1.164)\end{array}$ \\
\hline Gender & $\begin{array}{l}0.186^{* * *} \\
(0.0489)\end{array}$ & \\
\hline Entr. Parents & $\begin{array}{c}-0.141^{* * *} \\
(0.0509)\end{array}$ & \\
\hline $\begin{array}{l}\text { Constant } \\
\text { Observations }\end{array}$ & $\begin{array}{c}1.574 * * * \\
(0.0383) \\
7280\end{array}$ & $\begin{array}{c}0.327 * \\
(0.161) \\
375\end{array}$ \\
\hline $\mathrm{R}^{2}$ & & 0.053 \\
\hline
\end{tabular}

\section{Discussion}

Our study responds to recent calls from EE scholars to consider the teaching model adopted in entrepreneurship courses when assessing their impact (Nabi et al. 2017; Naia et al. 2014). We did this by uncovering the relationship between different EE teaching models and entrepreneurial learning outcomes. Our findings suggest that teaching models that include experiential-based learning (i.e., Supply-Demand, Demand, and DemandCompetence), such as labs and simulations, are generally better than courses that are exclusively based on traditional frontal lectures focused on knowledge transmission (i.e., Supply). On the other extreme, however, pure Competence Models are not significantly more effective than pure Supply Models. Focusing only on theory or only on real-world experiences are two extremes that generally present some flaws.

Our study also complements previous studies focusing on the effect of EE teaching models on entrepreneurial intentions (Padilla-Angulo et al. 2021) and activities (Sansone et al. 2021). As reported in these studies, practice-oriented rather than theory-oriented entrepreneurship courses seem to be more effective. Therefore, including concrete or simulated entrepreneurship experiences in EE courses seems to be useful not only for stimulating new venture creation, but also for pushing students toward entrepreneurial careers. Thus, this result provides an additional justification for the investment in practice-based educational offerings, which are typically more resource- and competence-demanding, especially in the digital learning environment that is becoming more diffused in the New Normal (Liguori and Winkler 2020).

\subsection{Contributions}

The findings of this exploratory study offer two main contributions to research on EE and its impact. First, we propose and empirically implement an approach to systematically 
describe the teaching model of EE courses using Béchard and Grégoire's (2005) analytical framework. By doing so, we respond to the recent calls urging scholars to provide a more indepth description of the EE course assessed in impact studies to advance our understanding of EE outcomes and the boundary conditions that make EE effective (Carpenter and Wilson 2021; Martínez-Gregorio et al. 2021; Yi and Duval-Couetil 2021). Moreover, some research has been done on comparing two or three teaching models, but hybrid models are rarely considered, leaving a literature gap on this topic (Nabi et al. 2017).

Second, by empirically showing that different teaching models are associated with various levels of entrepreneurial learning outcomes, our findings reinforce the idea that the manner in which entrepreneurship is taught does actually matter with regard to the impact produced by EE (Åstebro and Hoos 2021; Hahn et al. 2017). Therefore, the conceptual efforts to describe how EE is taught are of fundamental importance to advance the research on EE outcomes and provide more sophisticated suggestions for the design of EE programs (Martínez-Gregorio et al. 2021).

\subsection{Limitations and Future Research}

Before discussing the practical implications of this study, it is worth highlighting its limitations and the possible opportunities for future research they create. First, our exploratory study finds an association between the identified teaching models and learning outcomes using a cross-sectional research design that involves students attending EE in different universities and contexts. To prove causality more rigorously, we recommend scholars use other empirical approaches, such as experiments and quasi-experiments with pre- and post-intervention questionnaires, which are being increasingly demanded in EE research (Carpenter and Wilson 2021; Martínez-Gregorio et al. 2021). They could take advantage of our approach to discuss and identify the teaching models of EE courses and compare their treatment effects in (quasi-)experimental settings.

Second, while we focused on learning outcomes, future research could consider other more behavioural-oriented and long-term impacts (Nabi et al. 2017), such as entrepreneurial performance and career outcomes. This would offer a more in-depth understanding of how EE teaching models should be designed based on the specific objective that the course aims to achieve (e.g., encouraging venture creation vs. promoting awareness about entrepreneurship).

Finally, while we estimated the average effect of EE teaching models on students' learning, future research could introduce some contingencies to explore whether certain types of teaching models are more or less suited to specific types of audiences (cf. Padilla-Angulo et al. 2021). For example, it would be of interest to know which type of teaching model is best suited for female students, STEM students, students with prior entrepreneurial experience, and so on.

\subsection{Practical Implications}

This paper offers some guidance for the design of EE courses in the university context. Our findings suggest that incorporating experiential-based teaching approaches, such as labs, simulations, games and project works, in EE induces more confidence in students understanding of entrepreneurship and mastery of entrepreneurial skills. Such types of teaching tools could be combined with more theory-oriented approaches based on frontal lectures to provide basic knowledge about entrepreneurship along with the development of entrepreneurial skills. Classroom experiences could also be combined with projects that deal with real-world problems to enrich students' learning experience. To blend different teaching models, for example, entrepreneurship programs could be divided into modules with different teaching styles, goals and assessment procedures. Further, different types of teaching models could be administered through different channels (i.e., online vs. in person), taking advantage of the growing diffusion of hybrid teaching styles at universities during the COVID-19 pandemic (Liguori and Winkler 2020). 


\section{Conclusions}

Acknowledging that EE can be taught in different ways, in this study, we described and implemented a coding procedure to classify the teaching model adopted in entrepreneurship courses. We used this approach to uncover the relationship between different types of teaching models and university students' entrepreneurial learning outcomes. By demonstrating that practice-oriented entrepreneurship courses, rather than theory-oriented ones, are associated with higher levels of entrepreneurial learning, our paper contributes to the research on EE impact and to the design of EE offerings.

Considering the central role played by teaching models for students' learning, with this paper, we hope to encourage educators to continue searching for the right blend of teaching models for their courses and recommend that scholars continue exploring how the design of teaching models can improve EE outcomes.

Author Contributions: Conceptualization, I.C., D.H. and T.M.; methodology, I.C.; software, I.C. and D.H.; validation, I.C., D.H. and T.M.; formal analysis, I.C.; investigation, I.C.; resources, I.C., D.H. and T.M.; data curation, I.C.; writing — original draft preparation, I.C.; writing—review and editing, D.H. and T.M.; visualization, I.C., D.H. and T.M.; supervision, D.H. and T.M.; project administration, I.C. and T.M.; funding acquisition, T.M. All authors have read and agreed to the published version of the manuscript.

Funding: This research was funded by the Contamination Lab's project and Italian Ministry of Universities and Research (MIUR)_Programma Nazionale per la Ricerca 2015-2020, Directorial Decree no. 3158 of 29 November 2016 n. 3158.

Institutional Review Board Statement: Not applicable.

Informed Consent Statement: Not applicable.

Data Availability Statement: Not applicable.

Acknowledgments: We would like to thank Giulia De Nicola and Cinzia Rota for their help in the data collection process. We appreciate the insightful comments and feedback offered by participants at the XXXII RSA AiIG (Riunione Scientifica Annuale, Associazione italiana Ingegneria Gestionale) in Naples (October 2021).

Conflicts of Interest: The authors declare no conflict of interest.

\section{Notes}

A full description of the GUESSS project is continuously updated at the website www.guesssurvey.org (accessed on 29 July 2021). The 42 entrepreneurship courses investigated relate only to students actually taking part in the survey and, therefore, do not represent all the entrepreneurship courses taught at the 16 Italian universities considered.

3 A list of publications that include the GUESSS database is continuously updated at the website www.guesssurvey.org (accessed on 29 July 2021).

4 The text in Italic represents quotes from the official HC.LAB documentation.

\section{References}

Arasti, Zahra, Mansoreh Falavarjani, and Narges Imanipour. 2012. A study of teaching methods in entrepreneurship education for graduate students. Higher Education Studies 2: 2-10. [CrossRef]

Åstebro, Thomas, and Florian Hoos. 2021. Impact measurement based on repeated randomized rontrol trials: The case of a training program to encourages social entrepreneurship. Strategic Entrepreneurship Journal 15: 254-78. [CrossRef]

Åstebro, Thomas, Jing Chen, and Perter Thompson. 2011. Stars and misfits: Self-employment and labor market frictions. Management Science 57: 1999-2017. [CrossRef]

Béchard, Jean-Pierre, and Denis Grégoire. 2005. Understanding teaching models in entrepreneurship for higher education. In The Dynamics of Learning Entrepreneurship in a Cross-Cultural University Context. Edited by Kyrö Paula and Christophe Carrier. Tampere: Faculty of Education, University of Tampere, pp. 104-34.

Blenker, Per, Elmholdt Stine Trolle, Frederiksen Signe Hedeboe, Korsgaard Steffen, and Wagner Kathleen. 2014. Methods in entrepreneurship education research: A review and integrative framework. Education and Training 56: 697-715. [CrossRef]

Carpenter, Alex, and Rachel Wilson. 2021. A systematic review of experimental design studies looking at the effect of entrepreneurship education on higher education students? The International Journal of Management Education, 100541. [CrossRef] 
Cohen, Jacob, and Patricia Cohen. 1983. Applied Multivariate Regression/Correlation Analysis for Behavioral Sciences, 2nd ed. Hillsdale: Lawrence Erlbaun Associates.

Colombo, Massimo G., and Evila Piva. 2020. Start-ups launched by recent STEM university graduates: The impact of university education on entrepreneurial entry. Research Policy 49: 103993. [CrossRef]

Crayford, Judith, Colm Fearon, Heather McLaughlin, and Wim Van Vuuren. 2012. Affirming entrepreneurial education: Learning, employability and personal development. Industrial and Commercial Training 44: 187-93. [CrossRef]

Eesley, Charles E., and Yong Suk Lee. 2020. Do university entrepreneurship programs promote entrepreneurship? Strategic Management Journal 42: 833-61. [CrossRef]

Fayolle, Alain. 2013. Personal views on the future of entrepreneurship education. Entrepreneurship and Regional Development 25: 692-701. [CrossRef]

Fayolle, Alain, and Narjisse Lassas-Clerc. 2006. Essay on the Nature of Entrepreneurship Education. Paper presented at International Conference, Sunny Beach, Bulgaria, September 13-17.

Fiore, Eleonora, Giuliano Sansone, and Emilio Paolucci. 2019. Entrepreneurship education in a multidisciplinary environment: Evidence from an entrepreneurship programme held in Turin. Administrative Sciences 9: 28. [CrossRef]

Fyen, Wim, Koenraad Debackere, Maria Olivares, Roger Gfrörer, Erik Stam, Ben Mumby-Croft, and Laura Keustermans. 2019. Student Entrepreneurship at Research-Intensive Universities: From a Peripheral Activity toward a New Mainstream. League of European Research Universities, Pushing the Frontiers of Innovative Research. Leuven: LERU.

Gibb, Allan, Andrea R. Hofer, and Magnus Klofsten. 2018. The Entrepreneurial and Innovative Higher Education Institution: A Review of the Concepts and Its Relevance Today. HEInnovate. Available online: https://heinnovate.eu/sites/default/files/heinnovate_ concept_note.pdf (accessed on 29 July 2021).

Gibb, Allan A. 1993. Enterprise culture and education: Understanding enterprise education and its links with small business, entrepreneurship and wider educational goals. International Small Business Journal 11: 11-34. [CrossRef]

Hägg, Gustav, and Agnieszka Kurczewska. 2019. Who is the student entrepreneur? Understanding the emergent adult through the pedagogy and andragogy interplay. Journal of Small Business Management 57: 130-47. [CrossRef]

Hahn, Davide. 2020. The psychological well-being of student entrepreneurs: A social identity perspective. International Entrepreneurship and Management Journal 16: 467-99. [CrossRef]

Hahn, Davide, Dinah Isabel Spitzley, Mara Brumana, Attilia Ruzzene, Laura Bechthold, Reinhard Prügl, and Tommaso Minola. 2021a. Founding or succeeding? Exploring how family embeddedness shapes the entrepreneurial intentions of the next generation. Technological Forecasting and Social Change 173: 121182. [CrossRef]

Hahn, Davide, Tommaso Minola, Anita Van Gils, and Jolien Huybrechts. 2017. Entrepreneurial education and learning at universities: Exploring multilevel contingencies. Entrepreneurship and Regional Development 29: 945-74. [CrossRef]

Hahn, Davide, Tommaso Minola, Giulio Bosio, and Lucio Cassia. 2020. The impact of entrepreneurship education on university students' entrepreneurial skills: A family embeddedness perspective. Small Business Economics 55: 257-82. [CrossRef]

Hahn, Davide, Tommaso Minola, Ilaria Cascavilla, Silvia Ivaldi, and Mario Salerno. 2021b. Toward a theory-informed practice of entrepreneurship education for university students: The case of HC. LAB. Piccola Impresa/Small Business 1: 16-47. [CrossRef]

Hannon, Paul D. 2005. Philosophies of enterprise and entrepreneurship education and challenges for higher education in the UK. The International Journal of Entrepreneurship and Innovation 6: 105-14. [CrossRef]

Heinonen, Jarna, and Ulla Hytti. 2010. Back to basics: The role of teaching in developing the entrepreneurial university. The International Journal of Entrepreneurship and Innovation 11: 283-92. [CrossRef]

Karlsson, Tomas, and Kåre Moberg. 2013. Improving perceived entrepreneurial abilities through education: Exploratory testing of an entrepreneurial self-efficacy scale in a pre-post setting. The International Journal of Management Education 11: 1-11. [CrossRef]

Kennedy, Peter. 2008. A Guide to Econometrics. Malden: Blackwell Publishing.

Kirkwood, Jodyanne, Kirsty Dwyer, and Brendan Gray. 2014. Students' reflections on the value of an entrepreneurship education. The International Journal of Management Education 12: 307-16. [CrossRef]

Kuratko, Donald F., Jeffrey S. Hornsby, and Alexander McKelvie. 2021. Entrepreneurial mindset in corporate entrepreneurship: Forms, impediments, and actions for research. Journal of Small Business Management, 1-23. [CrossRef]

Lackéus, Martin. 2015. Entrepreneurship in Education: What, Why, When, How, Entrepreneurship 360. Background Paper. OECD Center for Entrepreneurship. Paris: OECD.

Lackéus, Martin. 2020. Comparing the impact of three different experiential approaches to entrepreneurship in education. International Journal of Entrepreneurial Behavior and Research 26: 937-71. [CrossRef]

Lackéus, Martin, and Carin Sävetun. 2019. Assessing the impact of enterprise education in three leading Swedish compulsory schools. Journal of Small Business Management 57: 33-59. [CrossRef]

Lautenschläger, Arndt, and Heiko Haase. 2011. The myth of entrepreneurship education: Seven arguments against teaching business creation at universities. Journal of Entrepreneurship Education 14: 147-61.

Leitch, Claire, Shirley-Anne Hazlett, and Luke Pittaway. 2012. Entrepreneurship education and context. Entrepreneurship and Regional Development 24: 733-40. [CrossRef]

Liguori, Eric, and Christoph Winkler. 2020. From offline to online: Challenges and opportunities for entrepreneurship education following the COVID-19 pandemic. Entrepreneurship Education and Pedagogy 3: 346-51. [CrossRef] 
Longva, Kjersti K., Øivind Strand, and Mark Pasquine. 2020. Entrepreneurship education as an arena for career reflection: The shift of students' career preferences after a business planning course. Education and Training 62: 877-96. Available online: https:/ / www.emerald.com/insight/0040-0912.htm (accessed on 29 July 2021). [CrossRef]

Lyons, Elizabeth, and Laurina Zhang. 2018. Who does (not) benefit from entrepreneurship programs? Strategic Management Journal 39: 85-112. [CrossRef]

Maguire, Malcom, and Mariarosa Lunati. 2009. Evaluation of Programmes Concerning Education for Entrepreneurship. OECD Working Party on SMEs and Entrepreneurship. Paris: OECD.

Martin, Bruce C., Jeffrey J. McNally, and Michael J. Kay. 2013. Examining the formation of human capital in entrepreneurship: A meta-analysis of entrepreneurship education outcomes. Journal of Business Venturing 28: 211-24. [CrossRef]

Martínez-Gregorio, Sara, Laura Badenes-Ribera, and Anita Oliver. 2021. Effect of entrepreneurship education on entrepreneurship intention and related outcomes in educational contexts: A meta-analysis. The International Journal of Management Education 19: 100545. [CrossRef]

McNally, Jeffrey J., Panagiotis Piperopoulos, Dianne H. Welsh, Thomas Mengel, Maha Tantawy, and Nikolaos Papageorgiadis. 2020. From pedagogy to andragogy: Assessing the impact of social entrepreneurship course syllabi on the millennial learner. Journal of Small Business Management 58: 871-92. [CrossRef]

Meoli, Azzurra, Riccardo Fini, Maurizio Sobrero, and Johan Wiklund. 2020. How entrepreneurial intentions influence entrepreneurial career choices: The moderating influence of social context. Journal of Business Venturing 35: 105982. [CrossRef]

Minola, Tommaso, Davide Donina, and Michele Meoli. 2016. Students climbing the entrepreneurial ladder: Does university internationalization pay off? Small Business Economics 47: 565-87. [CrossRef]

Nabi, Ghulam, Andreas Walmsley, Francisco Liñán, Imran Akhtar, and Charles Neame. 2018. Does entrepreneurship education in the first year of higher education develop entrepreneurial intentions? The role of learning and inspiration. Studies in Higher Education 43: 452-67. [CrossRef]

Nabi, Ghulam, Francisco Liñán, Alain Fayolle, Norris Krueger, and Andreas Walmsley. 2017. The impact of entrepreneurship education in higher education: A systematic review and research agenda. Academy of Management Learning and Education 16: 277-99. [CrossRef]

Naia, Ana, Rui Baptista, Carlos Januário, and Virgìnia Trigo. 2014. A systematization of the literature on entrepreneurship education: Challenges and emerging solutions in the entrepreneurial classroom. Industry and Higher Education 28: 79-96. [CrossRef]

Neck, Heidi M., and Patricia G. Greene. 2011. Entrepreneurship education: Known worlds and new frontiers. Journal of Small Business Management 49: 55-70. [CrossRef]

Nunnally, Jum C. 1978. Psychometric Theory. New York: McGraw Hill. Available online: http://hdl.handle.net/123456789/11061 (accessed on 29 July 2021).

O'Connor, Allan. 2013. A conceptual framework for entrepreneurship education policy: Meeting government and economic purposes. Journal of Business Venturing 28: 546-63. [CrossRef]

Padilla-Angulo, Laura, René Díaz-Pichardo, and Antonio L. Leal-Rodríguez. 2021. Are different entrepreneurship-promotion activities equally effective? An analysis by academic year and gender. International Entrepreneurship and Management Journal, 1-25. [CrossRef]

Piperopoulos, Panagiotis, and Dimo Dimov. 2015. Burst bubbles or build steam? Entrepreneurship education, entrepreneurial self-efficacy, and entrepreneurial intentions. Journal of Small Business Management 53: 970-85. [CrossRef]

Rauch, Andreas, and Willem Hulsink. 2015. Putting entrepreneurship education where the intention to act lies: An investigation into the impact of entrepreneurship education on entrepreneurial behavior. Academy of Management Learning and Education 14: 187-204. [CrossRef]

Rideout, Elaine C., and Denis O. Gray. 2013. Does entrepreneurship education really work? A review and methodological critique of the empirical literature on the effects of university-based entrepreneurship education. Journal of Small Business Management 51: 329-51. [CrossRef]

Roach, Michael, and Henry Sauermann. 2015. Founder or joiner? The role of preferences and context in shaping different entrepreneurial interests. Management Science 61: 2160-84. [CrossRef]

Roman, Eodora, and Alexandru Maxim. 2017. National culture and higher education as pre-determining factors of student entrepreneurship. Studies in Higher Education 42: 993-1014. [CrossRef]

Sansone, Giuliano, Daniele Battaglia, Paolo Landoni, and Emilio Paolucci. 2021. Academic spinoffs: The role of entrepreneurship education. International Entrepreneurship and Management Journal 17: 369-99. [CrossRef]

Shah, Sonali K., and Emily C. Pahnke. 2014. Parting the ivory curtain: Understanding how universities support a diverse set of startups. The Journal of Technology Transfer 39: 780-92. [CrossRef]

Shane, Scott, and Sankaran Venkataraman. 2000. The promise of entrepreneurship as a field of research. Academy of Management Review 25: 217-26. [CrossRef]

Sieger, Philipp, Urs Fueglistaller, and Thomas Zellweger. 2016. Student Entrepreneurship 2016: Insights from 50 Countries. International Report of GUESSS Project 2016. St. Gallen: KMU-HSG, Bern: IMU.

Souitaris, Vangelis, Stefania Zerbinati, and Andreas Al-Laham. 2007. Do entrepreneurship programmes raise entrepreneurial intention of science and engineering students? The effect of learning, inspiration and resources. Journal of Business Venturing 22: 566-91. [CrossRef] 
Volery, Thierry, Susan Müller, Fritz Oser, Catherine Naepflin, and Nuria Del Rey. 2013. The impact of entrepreneurship education on human capital at upper-secondary level. Journal of Small Business Management 51: 429-46. [CrossRef]

Wright, Mike, Donald S. Siegel, and Philippe Mustar. 2017. An emerging ecosystem for student start-ups. The Journal of Technology Transfer 42: 909-22. [CrossRef]

Yi, Soohyun, and Nathalie Duval-Couetil. 2021. Standards for evaluating impact in entrepreneurship education research: Using a descriptive validity framework to enhance methodological rigor and transparency. Entrepreneurship Theory and Practice, 1-32. [CrossRef] 